\title{
CORRECTION
}

\section{Correction to: Failure Analysis of Ball Bearing of Conveyor: Overusage}

\author{
Urbi Pal • Piyas Palit • Prabhash Gokarn - Samiran Kanrar
}

Published online: 10 November 2020

(C) ASM International 2020

\section{Correction to: J Fail. Anal. and Preven.} https://doi.org/10.1007/s11668-020-01014-5

In the original version of the article, Prabhash Gokarn's last name was misspelled. The original version of the article has been corrected.
Publisher's Note Springer Nature remains neutral with regard to jurisdictional claims in published maps and institutional affiliations.

The original article can be found online at https://doi.org/10.1007/ s11668-020-01014-5.

U. Pal $(\bowtie) \cdot$ P. Palit · P. Gokarn

Central Laboratories, Scientific Services Division, Tata Steel

Limited, Kalinganagar, India

e-mail: urbi.pal@tatasteel.com

S. Kanrar

Mechanical Design, Tata Steel Limited, Kalinganagar, India 